\title{
A Baltic heritage in Scotland: basement terrane transfer during the Grenvillian orogeny
}

\author{
R.A. Strachan ${ }^{1,2}$, T.E. Johnson ${ }^{2,3}$, C.L. Kirkland ${ }^{2}$, P.D. Kinny ${ }^{2} \&$ T. Kusky ${ }^{3}$ \\ 1. School of the Environment, Geography \& Geosciences, University of Portsmouth, \\ Portsmouth, PO1 3QL, UK. \\ 2. The Institute for Geoscience Research (TIGeR), Curtin University, GPO Box U1987, \\ Perth, WA 6845, Australia. \\ 3. State Key Laboratory of Geological Processes and Mineral Resources, Centre for Global \\ Tectonics, School of Earth Sciences, China University of Geosciences, Wuhan 430074, \\ China.
}

\begin{abstract}
Archean basement inliers within the Northern Highland Terrane (NHT), Scottish Caledonides, have been correlated with the Lewisian Gneiss Complex of the Laurentian foreland. New zircon $\mathrm{U}-\mathrm{Pb}$ ages indicate that the NHT basement contains evidence for magmatism at 2823$2687 \mathrm{Ma}$, and 1772-1655 Ma. The first group compares with crystallization ages of the foreland Archean gneisses. However, the second group, and a supracrustal unit, formed ca. 100-250 myr after the youngest major phase of juvenile magmatism and sedimentation in the foreland. Also, there is no indication within the NHT basement of the Palaeoproterozoic mafic and felsic intrusions common within the foreland, leading us to conclude that there is no firm basis for correlation of the two crustal blocks. The Caledonian Moine Thrust, which separates the foreland and the NHT basement, is thought to have reworked a Grenvillian suture indicated by the presence of the ca. 1100-1000 Ma Eastern Glenelg eclogites. On the basis of the new isotopic data, we propose that the NHT basement was a fragment of Baltica that was emplaced onto Laurentia during the Grenvillian orogeny, representing a further example of basement terrane transfer in the circum-North Atlantic orogens.
\end{abstract}

\section{INTRODUCTION}

Orogenic belts commonly contain exotic terranes emplaced tectonically from one craton onto another as large nappes during collisional orogeny. Subsequent rifting/breakup can then lead to separation of these terranes from their parent craton. Examples include the basement inliers of the southeast Appalachians derived from Amazonia during the 1100-1000 Ma Grenvillian 
orogeny (Fig 1; Hynes and Rivers, 2010), the Uppermost Allochthon of Norway derived from Laurentia during the 500-400 Ma Caledonian orogeny (Fig 1; Andersen and Andresen, 1994), and the Precordillera of Amazonia that also originated in Laurentia (Thomas et al., 2004). Thus, identifying exotic terranes enables insights into ancient cratonic configurations and plate reconstructions.

In NW Scotland, the Laurentian foreland of the Caledonian orogen is underlain by the Archean-Paleoproterozoic Lewisian Gneiss Complex (Figs. 1 and 2). The complex comprises different terranes (Kinny et al., 2005) that collectively record a protracted crustal evolution involving: (1) TTG magmatism at ca. 3100-2700 Ma; (2) high-grade metamorphism at ca. 2700 and $2500 \mathrm{Ma}$; (3) main phase intrusion of Scourie mafic dykes at ca. 2420-2380 Ma; (4) formation of Loch Maree Group supracrustals at ca. 1900 Ma, and; (5) Laxfordian reworking and high-grade metamorphism at ca. 1850 and ca. 1700-1650 Ma (e.g. Wheeler et al., 2010; Whitehouse and Kemp, 2010; Davies and Heaman, 2014). To the east, the Moine Thrust Zone separates the Laurentian foreland from the Northern Highland Terrane (NHT; Fig. 2). The NHT is dominated by the Neoproterozoic Moine Supergroup that is interleaved tectonically with inliers of orthogneissic basement (Fig. 2; Strachan et al., 2002; Cawood et al., 2015). Published $\mathrm{U}-\mathrm{Pb}$ zircon geochronology permits broad correlation of the NHT basement with the Lewisian Gneiss Complex (Friend et al., 2008), as does new Hf isotopic data. However, new U-Pb ages presented here lead us to propose that the NHT basement is exotic, a part of Baltica that was emplaced onto Laurentia during the Grenvillian orogeny.

\section{STRUCTURAL SETTING AND EXISTING GEOCHRONOLOGY OF THE NHT BASEMENT}

The NHT basement inliers (Fig. 2) mainly comprise mafic to intermediate orthogneisses and, locally, supracrustal rocks (e.g. Friend et al., 2008). The inliers were reworked at amphibolite facies during Neoproterozoic and Ordovician-Silurian (Caledonian) orogenic events (e.g. Cutts et al., 2010; Cawood et al., 2015), but contain evidence of older, higher-grade metamorphism. U-Pb (SIMS) zircon data from the Ribigill, Borgie, Farr and western GlenelgAttadale inliers (Fig. 2) suggest protolith ages of ca. 2900-2700 Ma (Friend et al., 2008) and the former three show isotopic disturbance at ca. 1740-1600 Ma. The protolith ages support correlation with the foreland Lewisian Gneiss Complex (Moorbath and Taylor, 1974) and a Laurentian affinity. However, greater tectonic complexity is indicated by the presence within the Eastern Unit of the Glenelg-Attadale inlier of eclogites that have yielded Sm-Nd mineral 
isochrons of $1082 \pm 22 \mathrm{Ma}$ and $1010 \pm 13 \mathrm{Ma}$, consistent with a Grenvillian-aged suture (Sanders et al., 1984; Storey et al., 2005).

\section{NEW ISOTOPIC CONSTRAINTS ON THE NHT BASEMENT}

Zircon $\mathrm{U}-\mathrm{Pb}$ geochronology and hafnium isotope analysis were carried out by split-stream laser ablation inductively-coupled plasma mass spectrometry (LA-ICPMS) on a range of NHT inlier lithologies (Fig. 2), including clasts eroded from the inliers and reworked into the overlying Moine rocks (details in the Data Repository). Hf isotope analyses were also undertaken on samples from four inliers dated by Friend et al. (2008). Zircon data is grouped based on internal textures visible in cathodoluminescence (CL) images and U-Pb systematics.

A mylonitic intermediate orthogneiss from the Loch Fada inlier (Fig. 2; RS-MTZ-1801) contains zircons with internal magmatic zoning, some nucleated on irregular-shaped structural cores. From sixty analyses, three age components are evident: a small group at ca. $2935 \mathrm{Ma}$ interpreted as an inherited population, and two major magmatic components at ca. $2823 \pm 14 \mathrm{Ma}$ and $2766 \pm 14 \mathrm{Ma}$ (Fig. 3). Values of $\varepsilon \mathrm{Hf}_{\mathrm{i}}$ for the magmatic populations ranged from -2.7 to +0.7 , corresponding to $\mathrm{T}_{\mathrm{DM}(2)}$ ages of 3160 to $3080 \mathrm{Ma}$ (Fig. 4).

A felsic orthogneiss from the Achininver inlier (Fig. 2; RS-TI-18-05) contains zircons with well-developed primary magmatic zoning. Eight analyses yielded a weighted mean ${ }^{207} \mathrm{~Pb} /{ }^{206} \mathrm{~Pb}$ age of $2736 \pm 14 \mathrm{Ma}$, interpreted as the magmatic crystallization age (Fig. 3). $\varepsilon \mathrm{Hf}_{\mathrm{i}}$ for these range from -4.2 to +3.3 , corresponding to $\mathrm{T}_{\mathrm{DM}(2)}$ of 3280 to $2950 \mathrm{Ma}$ (Fig. 4). An intermediate orthogneiss from the Achininver inlier (RS-TI-18-10) contained few zircons, most of which were normally discordant (Fig. 3). The most concordant analysis with a ${ }^{207} \mathrm{~Pb} /{ }^{206} \mathrm{~Pb}$ age $(2 \sigma)$ of $2687 \pm 28 \mathrm{Ma}$, is interpreted as the best estimate of the minimum protolith crystallization age. This analysis indicates a $\varepsilon \mathrm{Hf}_{\mathrm{i}}$ of -0.2 . Two clasts of felsic orthogneiss derived from the Achininver basement were sampled from a basal Moine conglomerate. Zircons from RS-TI-18-07 exhibited both oscillatory and homogeneous textures under CL. Thirteen analyses yielded a weighted mean ${ }^{207} \mathrm{~Pb} /{ }^{206} \mathrm{~Pb}$ age of $2701 \pm 16 \mathrm{Ma}(\mathrm{MSWD}=2.5)$ (Fig. 3), and ten analyses of oscillatory zoned zircon from RS-TI-18-09 yielded a weighted mean ${ }^{207} \mathrm{~Pb} /{ }^{206} \mathrm{~Pb}$ age of $2725 \pm 14 \mathrm{Ma}(\mathrm{MSWD}=2.5)$ (Fig. 3). Both are interpreted as magmatic crystallization ages. $\varepsilon \mathrm{Hf}_{\mathrm{i}}$ values ranged from -0.4 to +2.0 (sample $18-07$ ) and -3.4 to +1.0 (sample 18-09), corresponding to $\mathrm{T}_{\mathrm{DM}(2)}$ ages between 3330 and $2980 \mathrm{Ma}$ (Fig. 4).

Three samples were dated from the Loch Shin inlier (Fig. 2). An intermediate orthogneiss (RS-LSI-18-21) contained zircons with variable CL emission and texture, including oscillatory-zoned grains and homogeneous crystals. Thirteen analyses yielded a 
weighted mean ${ }^{207} \mathrm{~Pb} /{ }^{206} \mathrm{~Pb}$ age of $1772 \pm 39 \mathrm{Ma}(\mathrm{MSWD}=1.3)$ (Fig. 3), interpreted as the age of magmatic crystallization. With one exception, $\varepsilon \mathrm{Hf}_{\mathrm{i}}$ for these zircons ranges from -17.5 to 13.2, corresponding to $\mathrm{T}_{\mathrm{DM}(2)}$ of 3390 to $3180 \mathrm{Ma}$ (Fig. 4). In addition, numerous analyses from this sample define a crude discordia trend back to ca. $2545 \mathrm{Ma}$ (Fig. 3), interpreted as inherited zircon that either has lost radiogenic $\mathrm{Pb}$ at the magmatic age or was physically mixed with the magmatic component in the analytical volume. A deformed intrusive felsic sheet within the orthogneisses (RS-LSI-18-20) contained zircons that generally display idiomorphic zoning with evidence for some magmatic resorption. Nineteen analyses yielded a weighted mean ${ }^{207} \mathrm{~Pb} /{ }^{206} \mathrm{~Pb}$ age of $1711 \pm 19 \mathrm{Ma}(\mathrm{MSWD}=0.74)$ (Fig. 3), interpreted as the age of magmatic crystallization. $\varepsilon \mathrm{Hf}_{\mathrm{i}}$ ranges from +0.2 to +4.4 , corresponding to $\mathrm{T}_{\mathrm{DM}(2)}$ of 2310 to $2110 \mathrm{Ma}$. A biotite schist, part of a metasedimentary unit (RS-LSI-18-19), contained zircons of likely detrital origin that exhibit various internal textures, including concentric growth zoning, homogeneous domains and transgressive reabsorption fronts. Three analyses yielded a weighted mean ${ }^{207} \mathrm{~Pb} /{ }^{206} \mathrm{~Pb}$ age of $1802 \pm 51 \mathrm{Ma}(\mathrm{MSWD}=0.89)$ (Fig. 2), which we regard as the best estimate for the maximum age of deposition of the sedimentary precursor. $\varepsilon \mathrm{Hf}_{\mathrm{i}}$ for this group ranges from -2.0 to +6.0 .

An intermediate orthogneiss from the Swordly inlier (Fig. 2; RS-SI-18-13) contained zircons that display concentric growth zoning truncated at grain edges. The analytical data spread along the Concordia curve (Fig. 3). A correlation between higher U content and younger ${ }^{207} \mathrm{~Pb} /{ }^{206} \mathrm{~Pb}$ apparent ages is consistent with radiogenic $\mathrm{Pb}$ loss from a ca. $1655 \mathrm{Ma}$ magmatic component during a ca. 1008 Ma metamorphic overprint. $\varepsilon \mathrm{Hf}_{\mathrm{i}}$ values for the least disturbed are between +3.2 and +9.1 .

\section{DISCUSSION}

\section{Significance of the new isotopic data}

The isotopic data indicate that the NHT basement preserves evidence for two phases of magmatism: Group 1 is between ca. 2823 and ca. 2687 Ma, and Group 2 between ca. 1772 and ca. $1655 \mathrm{Ma}$. The former falls within the ca. 2905-2670 Ma protolith age range established for the NHT basement by Friend et al. (2008). The initial Hf isotope compositions for Group 1, including those of the Friend et al. (2008) samples (Fig. 4), are typically a few epsilon units either side of CHUR, consistent with derivation as TTG suite magmas from a mainly mafic precursor that was extracted from the mantle between ca. 3330 and $2950 \mathrm{Ma}$. The combined evidence from crystallization ages of inherited zircon cores points to limited involvement of 
differentiated crust at least ca. 3540 myrs old. The oldest of these cores have Hf isotopic values that lie along a broad Hadean-Eoarchean crustal evolutionary array.

Group 2 has not been recognized before in the NHT. Their Hf data are more varied than Group 1 (Fig. 4). Orthogneiss RS-LSI-18-21 has highly negative $\varepsilon \mathrm{Hf}_{\mathrm{i}}$ values that could plausibly represent re-melted Neoarchean crust similar in composition to Group 1, consistent with the inherited zircon component in this sample. By contrast, RS-LSI-18-20 and RS-SI-1813 have $\varepsilon \mathrm{Hf}_{\mathrm{i}}$ close to or greater than zero, which were likely derived from juvenile Paleoproterozoic mafic crust. Detrital zircons in the sedimentary cover to the Loch Shin inlier show a mixed provenance incorporating Hf from Archean and Proterozoic sources (e.g. Slagstad and Kirkland, 2017). Although the maximum depositional age constraint provided by the youngest detrital zircons is ca. $1802 \mathrm{Ma}$, deposition was likely younger than the ca. 1711 Ma age of RS-LSI-18-20, because the (meta)sedimentary rocks are not intruded by any (meta)igneous units.

A feature of the SIMS U-Pb data for the Archean inliers studied by Friend et al. (2008) was the strong disturbance ( $\mathrm{Pb}$ loss) in latest Paleoproterozoic time. The new LA-ICPMS data from the Loch Fada, Achininver and Loch Shin inliers generally lack this discordance signature. Another difference from the previous study is the evidence for additional major isotopic disturbance at ca. $1008 \mathrm{Ma}$ in the Swordly inlier.

\section{Comparison with the Lewisian Gneiss Complex}

Group 1 protolith ages from our new data fall within the range of ages obtained from the Archean gneisses of the Lewisian Gneiss Complex (Fig. 2; ca. 3135-2680 Ma; Friend and Kinny, 1995, 2001; Kinny and Friend, 1997; Love et al., 2004; Kinny et al., 2005; Goodenough et al., 2013), and the Hf isotopic compositions of the zircons are similar to the Lewisian also (Fig. 4). Further, although the Loch Fada and Achininver samples contained no evidence of younger metamorphic events, the Ribigill, Borgie and Farr inliers dated by Friend et al. (2008) provided evidence for isotopic disturbance between ca. 1740 and ca. $1600 \mathrm{Ma}$, which corresponds broadly to some mineral ages (titanite, rutile) from the Lewisian Gneiss Complex (Corfu et al., 1994). In contrast, there are two significant differences between the NHT inliers and the Lewisian Gneiss Complex of the foreland. Firstly, the Group 2 protolith ages and the Loch Shin supracrustal rocks formed at least ca. 100-250 myr after the youngest significant phase of juvenile magmatism and sedimentation recognized on the foreland, the ca. $1900 \mathrm{Ma}$ Loch Maree Group (Park et al., 2001). Furthermore, there is no indication in the inliers of the Scourie dykes that are common within the foreland basement (Storey et al., 2010) or the 
Laxfordian granites that are abundant within the Rhiconich Terrane (Fig. 2; Friend and Kinny, 2001; Goodenough et al., 2013).

\section{Is the NHT basement part of Laurentia?}

The issue addressed here is fundamental to the interpretation of many basement gneiss complexes. To what extent do differences in tectono-metamorphic and/or magmatic histories reflect the heterogeneous distribution of deformation, metamorphism and/or igneous activity rather than differences across collisional sutures? Isotopic data can assist in distinguishing between different crustal blocks although the results may be equivocal. Thus, the hafnium data presented here (Fig. 4) do not enable discrimination between Laurentia and Baltica, most likely because they were conjoined in successive continental assemblies in the Neoarchean (Superia; Bleeker and Ernst, 2006) and Paleoproterozoic (Nuna; Karlstrom et al., 2001) and hence record a very similar crustal evolution. However, U-Pb zircon and hafnium data in combination can provide additional insights into tectono-magmatic histories as shown by our comparison of the Lewisian Gneiss Complex and the NHT basement. In our view, these differences are greater than can be explained by the ca. $100 \mathrm{~km}$ likely displacement on the intervening Moine Thrust Zone (Strachan et al., 2002). We therefore question assignment of the NHT basement to Laurentia and propose an alternative tectonic model.

It is generally believed that Rodinia assembly during the late Mesoproterozoic culminated in the collision at ca. 1000 Ma of Amazonia with a combined Laurentia-Baltica (Fig. 1; Cawood and Pisarevsky, 2017, but see Slagstad et al., 2017). Prior to that, between ca. 1900 and $1200 \mathrm{Ma}$, the southern margin of Laurentia-Baltica was a relatively linear accretionary orogen (e.g. Karlstrom et al., 2001). At ca. 1270 Ma, present-day west Norway faced south (present-day coordinates), but by ca. 1000 Ma Baltica had rotated $\sim 90^{\circ}$ to face Rockall Bank and the Laurentian foreland of Scotland (Fig. 1; Cawood and Pisarevsky, 2006; Cawood et al., 2010). This rotation must have resulted in loss of oceanic lithosphere between Laurentia and Baltica. We interpret the ca. 1100-1000 Ma Eastern Glenelg eclogites to have formed along the suture across which Baltica and Laurentia were amalgamated before the collision of Amazonia. This could also account for the major isotopic disturbance at ca. 1008 $\mathrm{Ma}$ in the Swordly inlier and resetting of biotite ages in parts of the Caledonian foreland in Scotland (Cliff and Rex, 1989).

Our proposed model envisages that a northern arm of the Grenvillian orogen extended to Scotland (Fig. 1), and that the NHT basement may have originated from Baltica. Significant inliers of Archean-Paleoproterozoic basement occur in the Norwegian Caledonides, including 
the West Troms Basement Complex, which has been compared with the Lewisian Gneiss Complex (Fig. 1; Bergh et al., 2015; Laurent et al., 2019). Further investigation of these inliers may provide a match for the orphaned NHT basement. The NHT may not have originated as part of Laurentia as generally believed, but was more likely transferred from Baltica during the Grenvillian orogeny, representing a further example of basement terrane transfer in the circumNorth Atlantic orogens.

\section{ACKNOWLEDGMENTS}

We thank Tony Prave, Nick Gardiner, Kathryn Goodenough, Toby Rivers and an anonymous reviewer for comments, Noreen Evans, Brad McDonald and Kai Rankenburg for analytical assistance, and Mark Witton for drafting. TEJ acknowledges support from the State Key Laboratory for Geological Processes and Mineral Resources, China University of Geosciences, Wuhan (Open Fund GPMR201903). RAS acknowledges support from The Institute for Geoscience Research, Curtin University.

\section{REFERENCES}

Andersen, T.B., and Andresen, A., 1994, Stratigraphy, tectonostratigraphy and the accretion of outboard terranes in the Caledonides of Sunnhordland, West Norway: Tectonophysics, v. 231, p. 71-84, doi: 10.1016/0040-1951(94)90122-8.

Bergh, S.G., Corfu, F., Priyatkina, N., Kullerud, K., and Myhre, P.I., 2015, Multiple postSvecofennian 1750-1560 Ma pegmatite dykes in Archaean-Palaeoproterozoic rocks of the West Troms Basement Complex, north Norway: Geological significance and regional implications: Precambrian Research, v. 266, p. 425-439, doi: 10.1016/j.precamres.2015.05.035.

Bleeker, W., and Ernst, R., 2006, Short-lived mantle generated magmatic events and their dyke swarms: the key unlocking Earth's paleogeographic record back to $2.6 \mathrm{Ga}$, in: Hanski, E., Mertanen, S., Rämö, T., and Vuollo, J., eds., Dyke Swarms - Time Markers of Crustal Evolution, Taylor and Francis/Balkema, London, p. 3-26.

Cawood, P.A., and Pisarevsky, S., 2006, Was Baltica right-way up or upside down in the Neoproterozoic?: Journal of the Geological Society, London, v. 163, p. 753-759, doi: 10.1144/0016-76492005-126. 
Cawood, P.A., and Pisarevsky, S., 2017, Laurentia-Baltica-Amazonia relations during Rodinia assembly: Precambrian Research, v. 292, p. 386-397, doi: 10.1016/j.precamres.2017.01.031.

Cawood, P.A., Nemchin, A.A., Strachan, R.A., Prave, A.R., and Krabbendam, M., 2007, Sedimentary basin and detrital zircon record along East Laurentia and Baltica during assembly and breakup of Rodinia: Jounral of the Geological Society, London, v. 164, p. 257275, doi: 10.1144/0016-76492006-115.

Cawood, P.A., Strachan, R.A., Cutts, K.A., Kinny, P.D., Hand, M., and Pisarevsky, S., 2010, Neoproterozoic orogeny along the margin of Rodinia: Valhalla orogen, North Atlantic: Geology, v. 38, p. 99-102, doi: 10.1130/G30450.1.

Cawood, P.A., Strachan, R.A., Merle, R.E., Millar, I.L., Loewy, S.L., Dalziel, I.W., Kinny, P.D., Jourdan, F., Nemchin, A.A., and Connelly, J.N., 2015, Neoproterozoic to early Palaeozoic extensional and contractional history of East Laurentian margin sequences. the Moine Supergroup, Scottish Caledonides: Geological Society of America Bulletin, v. 127, p. 349-371, doi: 10.1130/B31068.1.

Cliff, R.A., and Rex, D.C., 1989, Evidence for a 'Grenville' event in the Lewisian of the northern Outer Hebrides: Journal of the Geological Society, London, v. 146, p. 921-924, doi: 10.1144/gsjgs.146.6.0921.

Corfu, F., Heaman, L.M., and Rogers, G., 1994, Polymetamorphic evolution of the Lewisian complex, NW Scotland, as revealed by $\mathrm{U}-\mathrm{Pb}$ isotopic compositions of zircon, titanite and rutile: Contributions to Mineralogy and Petrology, v. 117, p. 215-228, doi: 10.1007/BF00310864.

Cutts, K.A., Kinny, P.D., Strachan, R.A., Hand, M., Kelsey, D.E., Emery, M., Friend, C.R.L., and Leslie, A.G., 2010, Three metamorphic events recorded in a single garnet: coupled phase modelling with in situ LA-ICPMS, and SIMS geochronology from the Moine Supergroup, NW Scotland: Journal of Metamorphic Geology, v. 28, p. 249-267, doi: 10.1111/j.15251314.2009.00863.x.

Davies, J.H.F.L., and Heaman, L.M., 2014, New U-Pb baddeleyite and zircon ages from the Scourie dyke swarm: A long-lived large igneous province with implications for the Paleoproterozoic evolution of NW Scotland: Precambrian Research, v. 249, p. 180-198, doi: 10.1016/j.precamres.2014.05.007. 
Friend, C.R.L., and Kinny, P.D., 1995, New evidence for the protolith ages of Lewisian granulites, northwest Scotland: Geology, v. 23, p. 1027-1030, doi: 10.1130/00917613(1995)023<1027:NEFPAO>2.3.CO;2.

Friend, C.R.L., and Kinny, P.D., 2001, A reappraisal of the Lewisian Gneiss Complex: geochronological evidence for its tectonic assembly from disparate terranes in the Proterozoic: Contributions to Mineralogy and Petrology, v. 142, p. 198-218, doi: $10.1007 / \mathrm{s} 004100100283$.

Friend, C.R.L., Strachan, R.A., and Kinny, P.D., 2008, U-Pb zircon dating of basement inliers within the Moine Supergroup, Scottish Caledonides: implications of Archaean protolith ages: Journal of the Geological Society, London, v. 165, p. 807-815, doi: 10.1144/0016-76492007-125.

Goodenough, K.M., Crowley, Q.C., Krabbendam, M., and Parry, S.F., 2013, New U-Pb age constraints for the Laxford Shear Zone, NW Scotland: Evidence for tectono-magmatic processes associated with the formation of a Paleoproterozoic supercontinent: Precambrian Research, v. 233, p. 1-19, doi: 10.1016/j.precamres.2013.04.010.

Hynes, A., and Rivers, T., 2010, Protracted continental collision - evidence from the Grenville Orogen: Canadian Journal of Earth Sciences, v. 47, p. 591-620, doi: 10.1139/E10003.

Karlstrom, K.E., Ahall, K-I, Harlen, S.S., Williams, M.L., McLelland, J., and Geissman, J.W., 2001, Long-lived (1.8.-1.0 Ga) convergent orogen in southern Laurentia, its extensions to Australia and Baltica, and implications for refining Rodinia: Precambrian Research, v. 111, p. 5-30, doi: 10.1016/S0301-9268(01)00154-1.

Kinny, P.D., and Friend, C.R.L., 1997, U-Pb isotopic evidence for the accretion of different crustal blocks to form the Lewisian Complex of Northwest Scotland: Contributions to Mineralogy and Petrology, v. 129, p. 326-340, doi: 10.1007/s004100050340.

Kinny, P.D., Friend, C.R.L., and Love, G.J., 2005, Proposal for a terrane-based nomenclature for the Lewisian Gneiss Complex of NW Scotland: Journal of the Geological Society, London, v. 162, p. 175-186, doi: 10.1144/0016.764903-149.

Laurent, O., Auwera, J.V., Bingen, B., Bolle, O., and Gerdes, A., 2019, Building up the first continents: Mesoarchean to Paleoproterozoic crustal evolution in west Troms, Norway: 
inferred from granitoid petrology, geochemistry and zircon $\mathrm{U}-\mathrm{Pb} / \mathrm{Lu}-\mathrm{Hf}$ isotopes: Precambrian Research, v. 321, p. 303-327, doi: 10.1016/jprecamres.2018.12.020.

Love, G.J., Kinny, P.D., and Friend, C.R.L., 2004, Timing of magmatism and metamorphism in the Gruinard Bay area of the Lewisian Gneiss Complex: comparisons with the Assynt Terrane and implications for terrane accretion: Contributions to Mineralogy and Petrology, v. 146, p. 620-636, doi: 10.1007/s00410-003-0519-1.

Moorbath, S., and Taylor, P.N., 1974, Lewisian age for the Scardroy Mass: Nature, v. 250, p. 41-43, doi: 10.1038/25004a0.

Park, R.G., Tarney, J., and Connelly, J.N., 2001, The Loch Maree Group: Paleoproterozoic subduction-accretion complex in the Lewisian of NW Scotland: Precambrian Research, v. 105, p. 205-226, doi: 10.1016/S0301-9268(00)00112-1.

Sanders, I.S., Van Calsteren, P.W.C., and Hawkesworth, C.J., 1984, A Grenville Sm-Nd age for the Glenelg eclogite in northwest Scotland: Nature, v. 312, p. 439-440, doi: $10.1038 / 312439 \mathrm{a} 0$.

Slagstad, T., Roberts, N.M.W., and Kulakov, E., 2017, Linking orogens across a supercontinent: the Grenvillian and Sveconorwegian margins on Rodinia: Gondwana Research, v. 44, p. 109115, doi: 10.1016/j.gr.2016.12.007.

Slagstad, T., Kirkland, C.L., 2017; The use of detrital zircon data in terrane analysis: A nonunique answer to provenance and tectonostratigraphic position in the Scandinavian Caledonides. Lithosphere ; 9 (6): 1002-1011. doi: https://doi.org/10.1130/L663.1.

Spencer, C.J., Kirkland, C.L., Prave, A., Strachan, R., Pease, V., 2018, Crustal reworking and orogenic styles inferred from zircon Hf isotopes: Proterozoic examples from the North Atlantic region: Geoscience Frontiers, v. 10, p. 417-424, doi: 10.1016/j.gsf.2018.09.008

Storey, C.D., Brewer, T.S., and Temperley, S., 2005, P-T conditions of Grenville-age eclogite facies metamorphism and amphibolite facies retrogression of the Glenelg-Attadale Inlier, NW Scotland: Geological Magazine, v. 142, p. 605-615, doi: 10.1017/S001675680500110X.

Storey, C.D., Brewer, T.S., Anczkiewicz, R., Parrish, R., and Thirlwall, M.F., 2010, Multiple high-pressure metamorphic events and crustal telescoping in the NW Highlands of Scotland: 
Journal of the Geological Society, London, v. 167, p. 455-468, doi: 10.1144/0016-76492009024.

Strachan, R.A., Smith, M., Harris, A.L., and Fettes, D.J., 2002, The Northern Highland and Grampian terranes, in: Trewin, N., ed., Geology of Scotland ( $4^{\text {th }}$ edition). Geological Society, London, p. 81-147.

Thomas, W.A., Astini, R.A., Mueller, P.A., Gehrels, G.E., and Wooden, J.L., 2004, Transfer of the Argentine Precordillera terrane from Laurentia: Constraints from detrital zircon geochronology: Geology, v. 32, p. 965-968, doi: 10.1130/G20727.1.

Wheeler, J., Park, R.G., Rollinson, H.R., and Beach, A., 2010, The Lewisian Complex: insights into deep crustal evolution, in: Law, R.D. et al., eds., Continental Tectonics and Mountain Building: The Legacy of Peach and Horne, Geological Society, London, Special Publication, v. 335, p. 51-79, doi: 10.1144/SP335.4.

Whitehouse, M.J., and Kemp, A.I.S., 2010, On the difficulty of assigning crustal residence, magmatic protolith and metamorphic ages to Lewisian granulites: constraints from combined in situ U-Pb and Lu-Hf isotopes, in: Law, R.D. et al., eds., Continental Tectonics and Mountain Building: The Legacy of Peach and Horne, Geological Society, London, Special Publication, v. 335, p. 81-101, doi: 10.1144/SP335.5.

\section{FIGURE CAPTIONS}

Figure 1. Laurentia-Baltica-Amazonia reconstruction for mid-Neoproterozoic time showing: a) major Archean, Paleoproterozoic and Mesoproterozoic tectonic elements, and b) extent of the Lower Paleozoic Caledonian orogen of East Greenland, Scandinavia and the British Isles and its lateral extension into the Appalachians (modified from Cawood et al., 2007). Red arrow indicates the anticlockwise rotation of Baltica that occurred between c. $1270 \mathrm{Ma}$ and c. $1000 \mathrm{Ma}$ (see text for discussion). AI, Amazonian inliers; RB, Rockall Bank; UA, Uppermost Allochthon; WTBC, West Troms Basement Complex.

Figure 2. Inset: map of northern Scotland showing terrane subdivisions and location of main map. GA, Glenelg-Attadale inlier; GGF, Great Glen Fault; HBF, Highland Boundary Fault. MT, Moine Thrust. Main map: geology of north Sutherland showing sample locations. B, Borgie; F, Farr; R, Ribigill inliers. AT, Assynt Terrane; RT, Rhiconich Terrane (Kinny et al., 2005). 
341 Figure 3. Stacked Tera-Wasserburg U-Pb plot for zircon grains from the studied samples (see 342 also Supplementary Data).

343 Figure 4. Zircon $\varepsilon H f_{i}$ evolution plot for the analyzed samples. Also shown are the 344 compositional fields for analyses of zircon grains from Baltica and Laurentia (Spencer et al., 345 2018) and the Lewisian Gneiss Complex (Whitehouse and Kemp, 2010). s9612= Borgie 346 inlier; s9641 = Western Glenelg-Attadale inlier; s991 = Farr inlier; s992 = Ribigill inlier. 


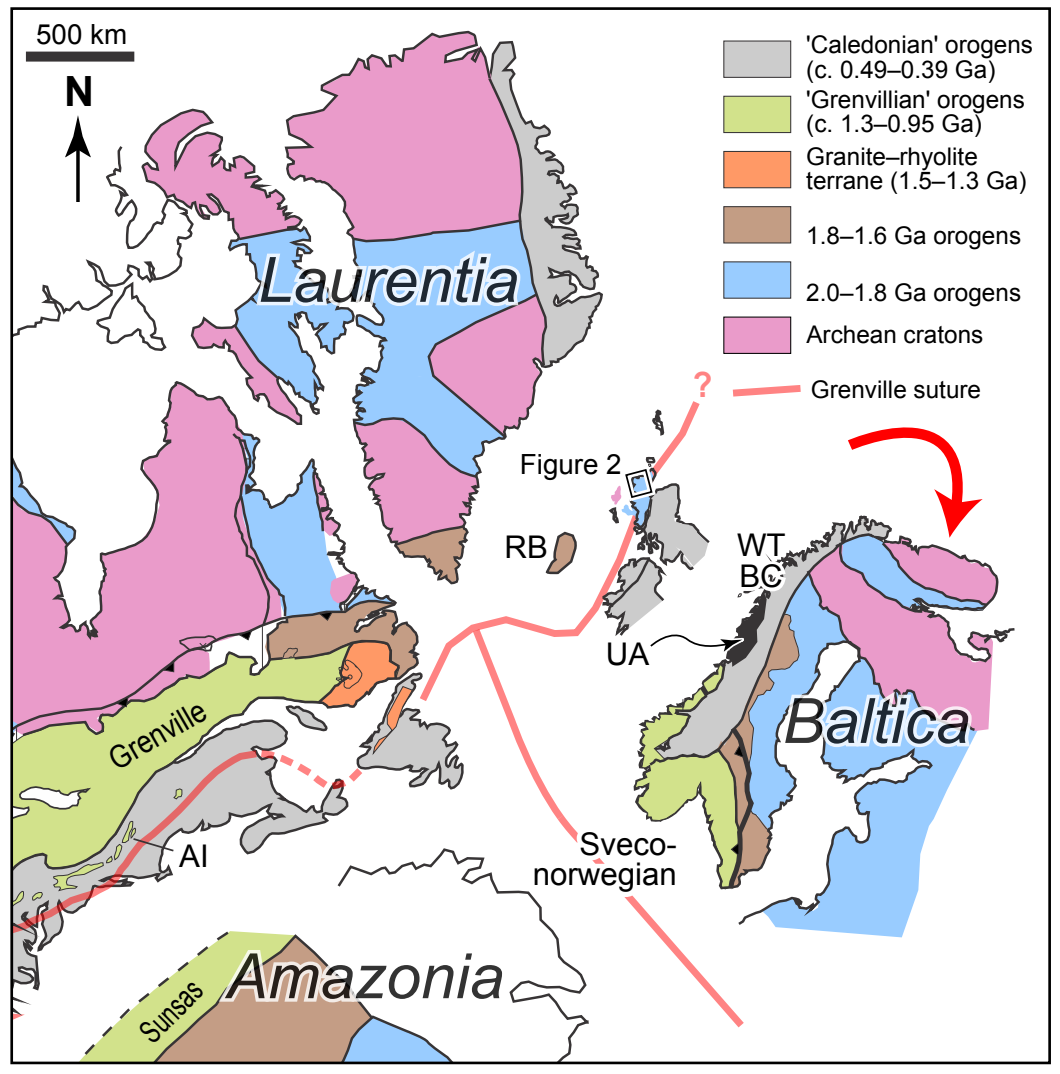

Strachan et al. Figure 1 


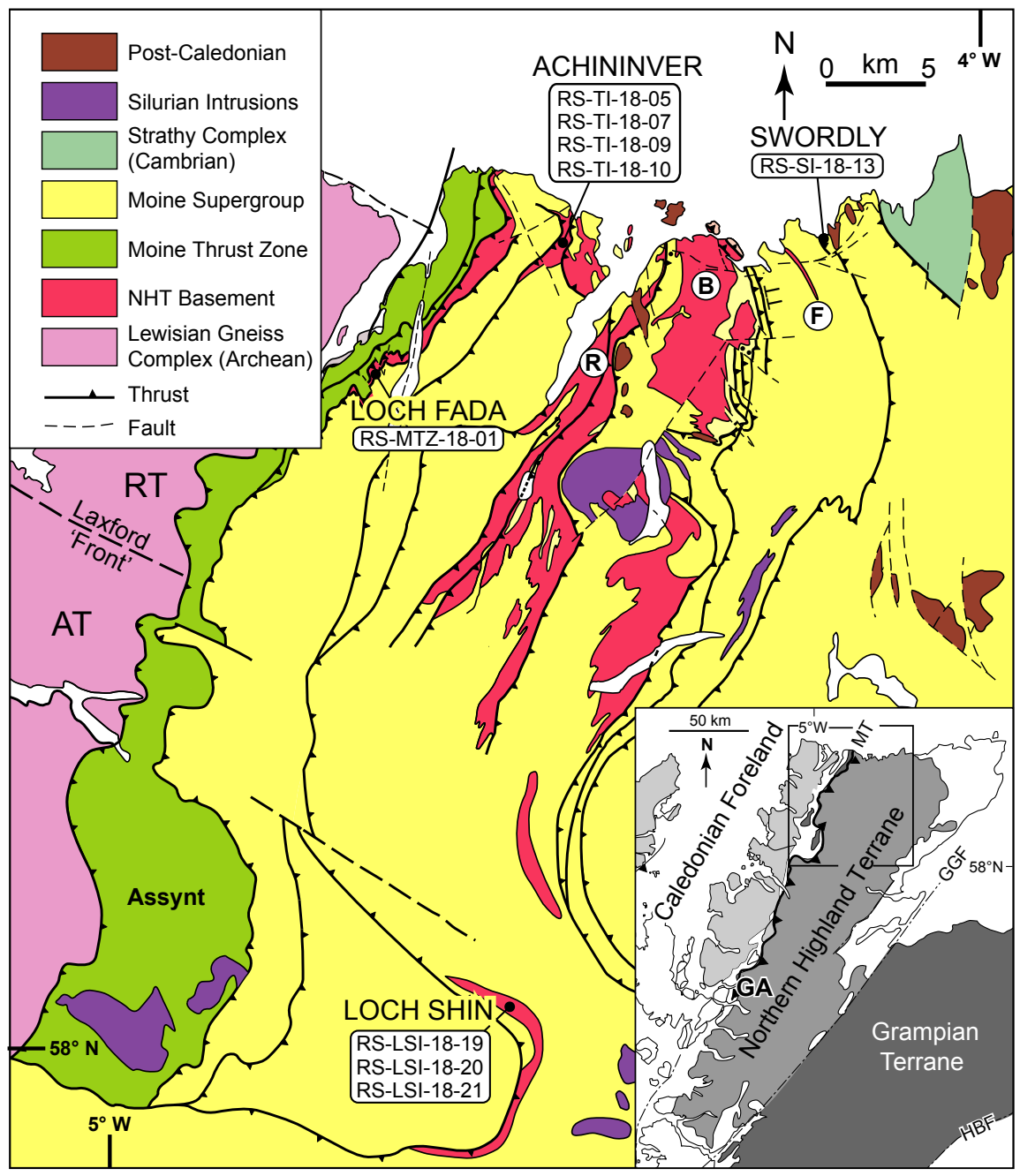

Strachan et al. Figure 2 
- Group D/Z/S = discordant/polyphase/detrital

- Group P = Pb-loss/mixtures

$\square$ Group I = magmatic

- Group $X=$ inherited

$\square$ Group $Y=$ youngest concordant population

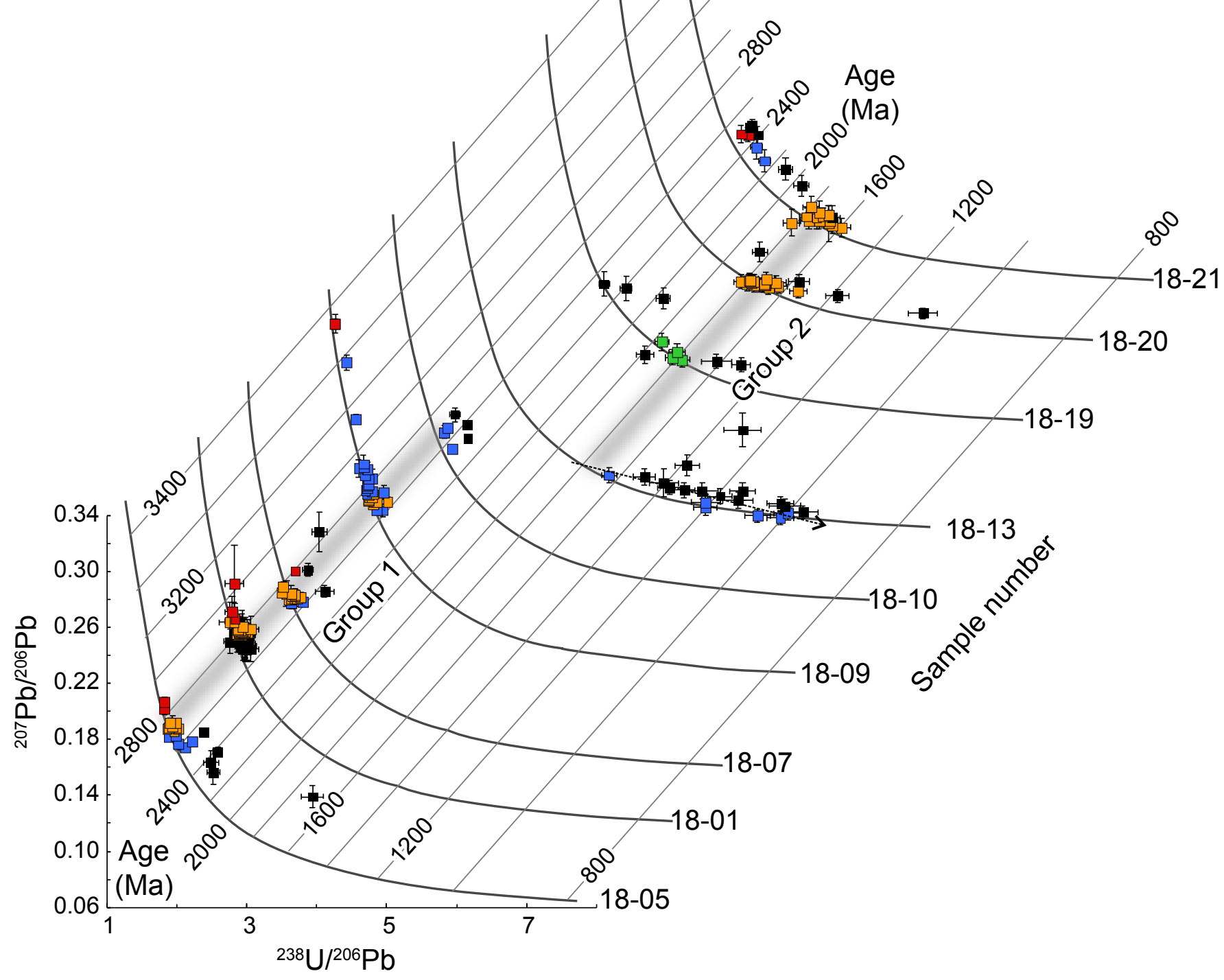

Strachan et al. Figure 3 


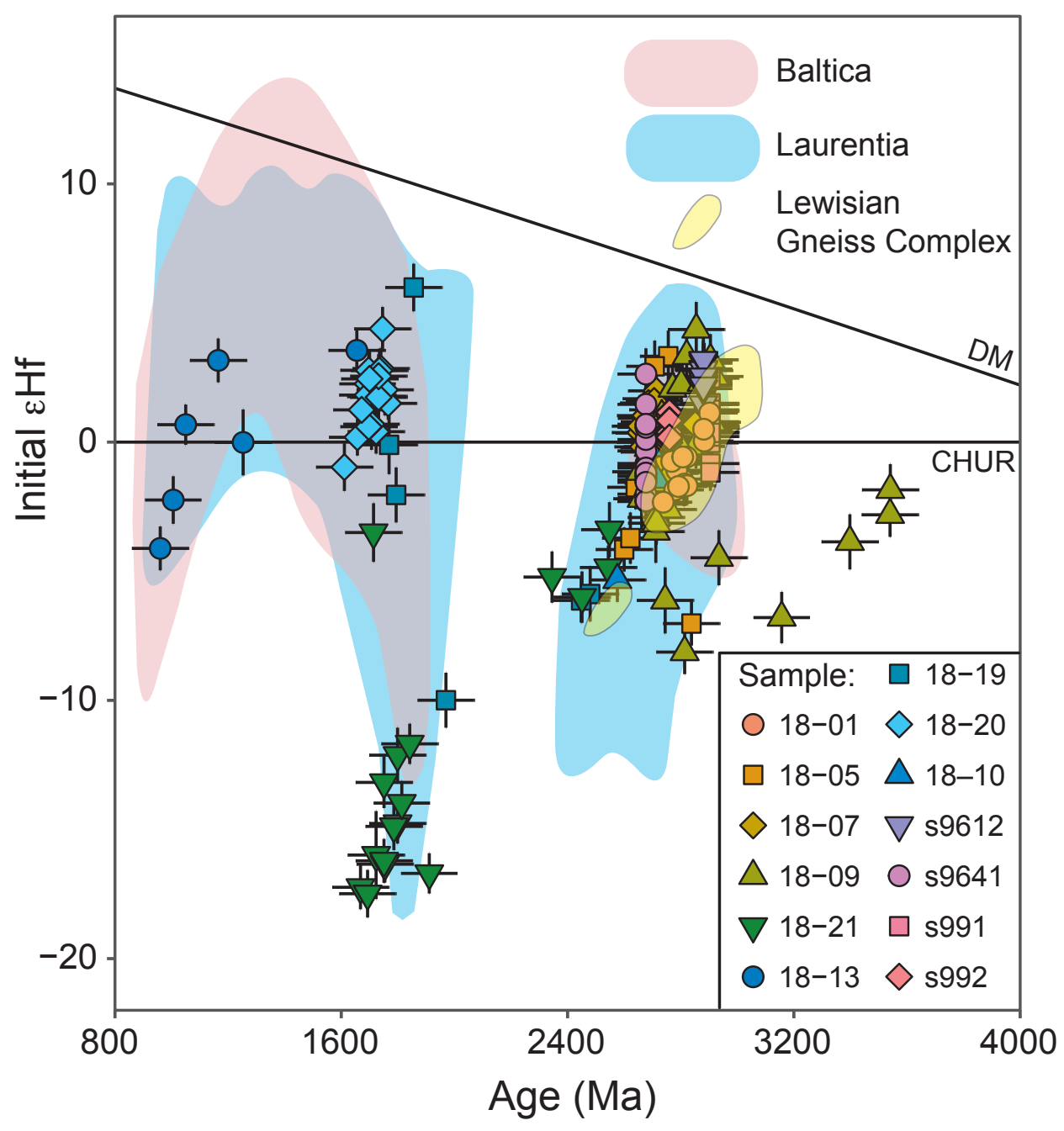

Strachan et al. Figure 4 